\title{
Pengaruh Budaya Organisasi Terhadap Kinerja Karyawan Pada PT Angkasa Pura II (Persero) Sultan Thaha Jambi
}

\author{
Muhammad Emil, Fadil Iskandar \\ Fakultas Ekonomi Universitas Batanghari \\ Corresponding email: muhammademil@gmail.com
}

\begin{abstract}
Second how the effect of organizational culture on employee performance at PT Angkasa Pura II (Persero) Sultan Thaha Jambi. The methodology is descriptive quantitative analysis methods. Data used is secondary data.The population become object in this research is employee performance at PT Angkasa Pura II (Persero) Sultan Thaha Jambi. The method for analysis is analysis simple regression, hypotesis test, correlation so determinant coefficient and t_test. The object of this research is PT Angkasa Pura II (Persero) Sultan Thaha Jambi. PT Angkasa PurA II (Persero) Sultan Thaha Airport in Jambi is subsidiary, which is engganged ini air transport services. The business priorities of the company are safety and comfort. Analysis on the research of respondents on score of organizational culture where indicators promoting organizational missions and motivational of higher while in teh discipline in which indicator score variables work with either is score 258 This can be interpreted as employees working in earnest. Simple regression equation model is $Y=5,295+0,713 X+e$. Test results of ttest is $t_{\text {count }}>t_{\text {table, }}$ in meaning the organizational culture has effect on performance employee. Conclusion, organizational culture and performance employee in good condition. So that organizational culture has effect significant to performance employee on PT Angkasa Pura II (Persero) Sultan Thaha. Suggestion that head manager of PT Angkasa Pura II (Persero) should directly control his subordinate work directly.
\end{abstract}

Keyword: curture organization, employee performance

\section{PENDAHULUAN}

Sumber daya manusia merupakan salah satu modal suatu organisasi baik organisasi pemerintahan maupun organisasi swasta, untuk mencapai tujuan atau target yang ingin dicapai. Yang mana manusia adalah unsur yang terpenting dalam setiap organisasi dalam merealisasikan tujuan dari organisasi. Keberhasilan organisasi untuk mencapai tujuan dan sasarannya serta kamampuannya menghadapi berbagai tantangan, baik yang bersifat internal maupun yang bersifat eksternal ditentukan oleh kualitas sumber daya manusia. Menyadari akan semakin pentingnya sumber daya manusia dalam suatu organisasi, maka pengelolaan sumber daya manusia perlu diperhatikan. Karena kunci sukses organisasi bukan hanya terbentuk pada tersedianya modal yang cukup dan keunggulan saja, tapi lebih dari itu sangat tergantung pada sumber daya manusia. Pengelolaan sumber daya manusia sangat berkaitan dengan pelaksanaan fungsi-fungsi manajemen pada organisasi tersebut. Pelaksanaan sumber daya manusia yang baik akan mendorong peningkatan kinerja karyawan.

Penilaian kinerja (performance appraical) dalam rangka pengembangan sumber daya manusia mempunyai arti penting. Hal ini terjadi karena setiap orang sebagai sumber daya manusia ingin mendapatkan penghargaan dan perlakuan yang adil dari pemimpin organisasi yang bersangkutan. Adanya penilaian kinerja yang baik, dapat menjamin karyawan untuk memperoleh kesempatan menempati posisi pekerjaan sesuai dengan kemampuannya. Dengan kata lain adanya penilaian kinerja erat kaitannya dengan pengembangan karir karyawan. Kinerja merupakan suatu hasil kerja yang dicapai seseorang dalam melaksanakan tugas-tugas yang dibebankan kepadanya yang didasarkan atas kecakapan, pengalaman dan kesungguhan serta waktu. Peningkatan kinerja karyawan dalam suatu organisasi sangat diperlukan agar tujuan yang diinginkan oleh organisasi dapat direaliasikan dengan baik. Kinerja suatu organisasi akan meningkat apabila terdapat kerjasama dan hubungan yang baik antara pimpinan dan karyawannya. Dengan meningkatkan kinerja karyawan akan meningkatkan kinerja perusahaan. Untuk itu karyawan sebaiknya diperlakukan sebagai partner kerja dan bukan sebagai pekerja semata.

Untuk mendapatkan kinerja karyawan sesuai dengan yang diharapkan, organisasi mempunyai tugas untuk memberikan dorongan kepada para karyawan, agar mereka bekerja dengan giatnya sehingga mencapai target organisasi. Secara teori berbagai definisi tentang motivasi biasanya terkandung keinginan, harapan, kebutuhan, tujuan, sasaran, dorongan dan insetif. Karyawan bekerja dengan harapan akan memperoleh upah/gaji yang dapat untuk memenuhi kebutuhan tersebut. Dorongan seseorang untuk bekerja dipengaruhi adanya kebutuhan yang harus dipenuhi dan tingkat kebutuhan yang berbeda pada setiap karyawan, sehingga dapat terjadi perbedaan motivasi dalam berprestasi. Selain itu, pemenuhan kebutuhan dari para karyawanan akan pelayanan dan penghargaan oleh atasan terhadap prestasi kerja yang dihasilkan yang sesuai dengan prinsip keadilan dapat memotivasi kerja mereka. Organisasi sendiri juga berperan dalam mengelola karyawan agar mematuhi segala peraturan, norma yang telah ditetapkan oleh organisasi sehingga para karyawan bekerja dengan disiplin dan efektif. 
Berbagai aturan/norma yang ditetapkan oleh suatu organisasi memiliki peran yang sangat penting dalam menciptakan kedisiplinan agar para karyawan dapat mematuhi dan melaksanakan peraturan tersebut. Aturan atau norma tersebut biasanya diikuti oleh sanksi yang diberikan apabila adanya palanggaran. Sanksi tersebut bisa berupa teguran baik lisan maupun tulisan, skorsing, penurunan pangkat bahkan sampai pemecatan tergatung dari besarnya pelanggaran yang dilakukan oleh karyawan.Melalui mekanisme pengaturan kinerja karyawan akan diketahui seberapa baik karyawan telah melaksanakan tugas-tugas yang diberikan kepadanya. Penilaian kinerja juga dapat digunakan perusahaan untuk mengetahui kekurangan dan potensi seorang karyawan. Dari hasil tersebut, perusahaan dapat mengembangkan suatu perencanaan sumber daya manusia secara menyeluruh dalam menghadapi masa depan perusahaan. Perencanaan sumber daya manusia secara menyeluruh tersebut berupa jalur-jalur karir atau promosi-promosi jabatan para karyawannya. Oleh karena itu perlu ditunjang oleh budaya yang baik di dalam suatu organisasi agar dapat meningkatkan kinerja karyawan yang sudah direncanakan oleh organisasi.

Setiap organisasi memiliki ciri khas yang membedakannya dengan organisasi lain, ciri khas ini menjadi identitas bagi organisasi. Ciri khas inilah yang dinamakan budaya organisasi. Budaya organisasi mengacu pada hubungan yang unik dari norma-norma, nilai-nilai, kepercayaan dan cara berperilaku yang menjadi ciri bagaimana kelompok dan individu dalam menyelesaikan sesuatu. Budaya organisasi mengandung nilai-nilai yang harus dipahami, dijiwai, dan dipraktikkan bersama oleh semua individu/kelompok yang terlibat didalamnya. Budaya yang ada pada suatu organisasi akan mempengaruhi cara pekerjaan dilakukan dan cara para pekerja berperilaku serta menyebabkan para pekerja memiliki cara pandang yang sama dalam melaksanakan aktivitas pekerjaan. Budaya organisasi juga akan memiliki dampak pada efisiensi dan efektivitas organisasi. Budaya organisasi juga berkaitan erat dengan pemberdayaan karyawan (employee empowerment) di suatu organisasi. Budaya organisasi dapat membantu kinerja karyawan, karena menciptakan suatu tingkat motivasi yang besar bagi karyawan untuk memberikan kemampuan terbaiknya dalam memanfaatkan kesempatan yang diberikan oleh organisasinya.

Semakin kuat budaya organisasi, semakin besar dorongan para karyawan untuk maju bersama dengan organisasi. Sehingga dapat menciptakan kinerja karyawan yang efektif dan efisien. Berdasarkan hal tersebut, pengenalan, penciptaan, dan pengembangan budaya organisasi dalam suatu organisasi mutlak diperlukan dalam rangka membangun organisasi yang efektif dan efisien sesuai dengan visi dan misi yang hendak dicapai. PT Angkasa Pura II (Persero) merupakan perusahaan yang mempunyai tugas mengelola Bandar Udara Sultan Thaha yang terletak di Kota Jambi. Yang mana bandara tersebut adalah bandara yang mempunyai standard nasional. Oleh sebab itu layak dijadikan objek suatu penelitian. Adapun alasannya adalah PT Angkasa Pura II (Persero) merupakan salah satu BUMN yang menjalankan bisnis pelayanan jasa kebandar udaraan. Selanjutnya perusahaan tersebut harus mempunyai kualitas performance yang baik standar nasional dan dapat dipercaya oleh masyarakat. Selanjutnya penelitian ini bertujuan untuk melihat bagaimana budaya organisasi terhadap kinerja karyawan pada PT Angkasa Pura II (Persero) Sultan Thaha Jambi.

\section{Budaya Organisasi}

Budaya organisasi adalah suatu nilai-nilai yang dipercayai sehingga menjadi karakteristik yang diberikan anggota kepada suatu organisasi. Budaya organisasi merupakan lingkungan internal suatu organisasi karena keragaman budaya yang ada dalam suatu organisasi sama banyaknya dengan jumlah individu yang ada dalam organisasi tersebut sehingga budaya organisasi sebagai pemersatu budaya-budaya yang ada pada diri individu untuk menciptakan tindakan yang dapat diterima dalam organisasi. Budaya organisasi berarti suatu sistem nilai yang unik, keyakinan, dan normanorma yang dimiliki secara bersama oleh anggota suatu organisasi

Menurut Fathoni (2016:146) bahwa budaya organisasi merupakan gambaran perspektif dari budaya dalam organisasi. Sedangkan menurut Umar (2013:112), budaya organisasi adalah suatu pola dari dasar asumsi untuk bertindak, menentukan, atau mengembangkan anggota organisasi dalam mengatasi persoalan dengan mengadaptasinya dari luar dan mengintegrasikan ke dalam organisasi. Mangkunegara (2014:211) menyimpulkan bahwa budaya organisasi adalah seperangkat asumsi atau sistem keyakinan, nilai-nilai dan norma yang dikembangkan dalam organisasi yang dijadikan pedoman tingkah laku bagi anggotaanggotanya untuk mengatasi masalah adaptasi eksternal dan integrasi internal. Tujuan keberadaan budaya suatu organisasi adalah melengkapi para anggota dengan rasa (identitas) organisasi dan menimbulkan komitmen terhadap nilai-nilai yang dianut organisasi. Di dalam suatu organisasi peran budaya dalam mempengaruhi perilaku karyawan tampaknya semakin penting. Budaya organisasi dapat tercermin diantaranya dari sistem yang meliputi besar kecilnya kesempatan berinovasi dan berkreasi bagi karyawan, pembentukan tim-tim kerja, kepemimpinan yang transparan dan tidak terlalu birokratis. Karakteristik tersebut yang dipersepsi oleh karyawan sebagai budaya organisasi, diharapkan dapat berfungsi dalam memberikan kepuasan kerja dan kinerja yang optimal dalam upaya mencapai tujuan organisasi. 


\section{Kinerja}

Menurut Simamora (2017:88), kinerja (performance) mengacu kepada kadar pencapaian tugas - tugas yang membentuk sebuah pekerjaan karyawan. Sedangkan menurut Mondy (2014:110), kinerja merupakan proses berorientasi dimana para karyawan diarahkan untuk memaksimalkan produktivitasnya. Menurut Rivai,(2015:68) kinerja adalah hasil atau tingkat keberhasilan seseorang atau keseluruhan selama periode tertentu di dalam melaksanakan tugas dibandingkan dengan berbagai kemungkinan, seperti standar hasil kerja, target atau sasaran atau kriteria yang telah ditentukan terlebih dahulu dan telah disepakati bersama.

Suatu kinerja karyawan dapat dikatakan baik apabila terdapat suatu sistem formal yang dapat digunakan untuk menilai dan mengevaluasi kinerja tugas individu. Sistem formal untuk mengevaluasi kinerja individu tersebut disebut penilaian kinerja. Menurut Rivai (2005:73), penilaian kinerja dapat efektif apabila instrumen penilaian kinerja memenuhi syarat-syarat berikut ini : (1) Reliability, yaitu ukuran kinerja harus konsisten. Mungkin yang paling penting adalah konsistensi suatu ukuran kinerja. Jika ada dua penilai mengevaluasi pekerja yang sama, mereka perlu menyimpulkan hasil serupa menyangkut hasil mutu pekerja. (2) Relevance, yaitu ukuran kinerja harus dihubungkan dengan output riil dari suatu kegiatan yang secara logika itu mungkin. (3) Sensitivity, yaitu beberapa ukuran harus mampu mencerminkan perbedaan antara penampilan nilai tinggi dan rendah. Penampilan tersebut harus dapat membedakan dengan teliti tentang perbedaan kinerja. (3) Practicality, yaitu kriteria harus dapat diukur, dan kekurangan pengumpulan data tidak terlalu mengganggu atau tidak in-efisien.

Selain itu, Simamora (2017:105) mengatakan bahwa standar kinerja pekerjaan mempunyai dua fungsi, yaitu : menjadi tujuan atau sasaran upaya karyawan, artinya setelah standard terpenuhi, karyawan akan merasakan adanya pencapaian dan penyelesaian. Kemudian fungsi yang kedua ialah standard kinerja pekerjaan merupakan kriteria pengukuran keberhasilan sebuah pekerjaan. Kinerja hendaknya mengandung dua komponen penting yaitu kompetensi yang berartiindividu atau organisasi memiliki kemampuan untuk mengidentifikasikan tingkat kinerjanya, dan produktivitas kompetensi tersebut di atas dapat diterjemahkan ke dalam tindakan atau kegiatan kegiatan yang tepat untuk mencapai hasil kinerja (outcome) (Dharma,2012:112).

\section{METODE}

Metode penelitian pada penelitian ini yaitu deskriptif kuantitatif. Artinya adalah suatu metode penelitian yang mengambil sampel dari suatu populasi dan menggunakan kuisioner sebagai alat pengumpul.
Dalam penelitian ini data dan informasi dikumpulkan dari responden dengan menggunakan kuisioner. Setelah data diperoleh kemudian hasilnya dipaparkan secara deskriptif. Pada akhir penelitian akan dianalisis untuk menguji hipotesis yang diajukan pada awal penelitian ini (Efendi,2013:3)

Pada penelitian ini data yang digunakan adalah kedua (2) jenis data tersebut. Data primer berupa kuisioner dan data sekunder berupa data-data yang didapat dari instansi yang menjadi objek penelitian. Adapun menurut Syech (2011:56) sumber data adalah dari mana data-data berasal. Dalam penelitian ini berasal dari PT Angkasa Pura II (Persero) Sultan Thaha Jambi. Sampel merupakan bagian atau wakil populasi yang memiliki karakteristik yang sama dengan populasinya (Sugiyono,2016:82). Pengambilan sampel dilakukan dengan menggunakan teknik accidental sampling. Accidental sampling adalah teknik penentuan sampel berdasarkan responden yang kebetulan ditemui oleh peneliti pada saat pengumpulan data. Dari populasi yang berjumlah 172 responden, maka diambil sampel dengan menggunakan metode slovin. Didapat jumlah responden ada: 64 responden .

\section{Alat Analisis \\ Rentang Skala}

Untuk menganalisis rumusan masalah terdahulu digunakan skala penelitian dengan menghitung frekuensi skor setiap item pertanyaan. Seperti yang dikemukakan Umar (2013:87), bahwa perhitungan skor setiap komponen yang diteliti dengan mengalikan seluruh frekuensi data dengan nilai bobot.

\section{Analisis Regresi Linier Sederhana}

Untuk menjawab tujuan penelitian kedua (2) digunakan analisis regresi linier sederhana. Menurut Supardi (2013:229), regresi linear sederhana merupakan persamaan dari dua variabel yakni variabel independen dan variabel dependen yang saling mempunyai hubungan. rumus persamaan regresi linier sederhana adalah sebagai berikut :

$$
\mathbf{Y}=\mathbf{a}+\mathbf{b X}+\mathbf{e}
$$

\section{Uji Hipotesis}

Uji t

Uji $t$ digunakan untuk menentukan apakah variabel bebas (budaya organisasi)/(X) berpengaruh signifikan terhadap variabel terikat (kinerja karyawan)/ (Y)

\section{Koefisien Korelasi dan Determinasi}

Menurut Kurniawan (2009:26) korelasi adalah hubungan atau keeratan antara 2 variabel, dimana terdiri dari 1 variabel independen (bebas) dan 1 variabel dependen (terikat) dan juga mengetahui arah hubungan. 
Menurut Supardi (2013:188) koefisien determinasi dilambangkan dengan $\mathrm{R}^{2}$. Nilai ini menyatakan proporsi variasi keseluruhan dalam nilai dependen yang dapat diterangkan atau diakibatkan oleh hubungan linear dsengan variabel independen, selain itu (sisanya) diterangkan oleh variabel yang lain (galat atau peubah lainnya).

\section{HASIL DAN PEMBAHASAN Analisis Deskriptif}

Berdasarkan hasil analisis deskriptif, bahwa data responden yang menjawab indikator disiplin kerja dapat terlihat pada tabel dibawah ini :

Tabel 1. Budaya Organisasi

\begin{tabular}{clcc}
\hline No & \multicolumn{1}{c}{ Indikator } & $\begin{array}{c}\text { Rata-rata } \\
\text { Skor }\end{array}$ & Keterangan \\
\hline 1. & Perilaku Pemimpin & 241 & Tinggi \\
2. & Mengedepankan Misi & 258 & Tinggi \\
& Organisasi & & \\
3. & Proses Pembelajaran & 255 & Tinggi \\
4. & Budaya organisasi & 258 & Tinggi \\
\hline Rata-rata & 253 & Tinggi \\
\hline
\end{tabular}

Skor variabel independent (Budaya Organisasi) dimana rata-rata skornya sebesar 253 kategori Tinggi, ini menunjukan bahwa responden merasa mempunyai budaya organisasi yang tinggi dalam pelaksanaan tugastugas yang diberikan oleh atasannya. Pada pernyataan responden indikator mengedepankan misi organisasi dan budaya organisasi menunjukan skor tertinggi, yakni skor sebesar 253 kategori baik. Maknanya bahwa karyawan pada PT Angkasa Pura II (Persero) Sultan Thaha Jambi giat, sungguh-sungguh dan mempunyai budaya organisasi yang tinggi dalam melaksanakan pekerjaan yang sudah direncanakan oleh kantor pusat dari PT Angkasa Pura II (Persero).

Selanjutnya pada variabel kinerja karyawan pada PT Angkasa Pura II (Persero) Sultan Thaha Jambi dapat terlihat pada tabel 2, yakni sebagai berikut:

Tabel 2. Kinerja Karyawan

\begin{tabular}{clcc}
\hline No & \multicolumn{1}{c}{ Indikator } & Rata-rata Skor & Keterangan \\
\hline 1. & Kualitas Kerja & 268 & Baik \\
2. & Inisiatif & 246 & Baik \\
3. & Ketepatan Waktu & 255 & Baik \\
4. & Kemampuan & 253 & Baik \\
5. & Komunikasi & 253 & Baik \\
\hline Rata-rata & 259 & baik \\
\hline
\end{tabular}

Skor variabel kinerja karyawan dimana rata-rata skornya sebesar 259 ini menunjukan bahwa kinerja karyawan pada PT Angkasa Pura II (Persero) Sultan Thaha Jambi baik. Pada indikator kualitas kerja , pernyataan responden dalam melakukan pekerjaan selalu hati-hati agar tidak membuat kesalahan dalam mengerjakan. Dimana pada pernyataan ini menunjukan skor tertinggi dari beberapa indikator dari variable kinerja karyawan yakni sebesar 268 kategori baik . Ini dapat disimpulkan bahwa dalam melakukan pekerjaan, karyawan pada PT Angkasa Pura II (Persero) Sultan Thaha Jambi selalu diselesaikan dengan hati-hati dan tanpa kesalahan. Sehingga pekerjaan diselesaikan dengan baik dan kecil resiko kecelakaan.

\section{Uji Kualitas Data}

Kualitas data yang dihasilkan dari penggunaan instrument penelitian dapat dievaluasi melalui uji validitas dan uji reliabilitas. Uji tersebut masing-masing untuk mengetahui akurasi data yang dikumpulkan dari penggunaan instrumen. Data penelitian tidak bermanfaat apabila instrumen yang digunakan untuk mengumpulkan data penelitian tidak memiliki reliabilitas dan validitas yang tinggi (Supandi,2013:89). Uji Kualitas data dilakukan menggunakan uji Validitas dengan Korelasi Pearson dan Uji realibilitas dengan Cronbach Alpha.

\section{Uji Validitas}

Uji validasi ini dimaksudkan untuk mengetahui apakah alat ukur dari variabel yang diingikan sesuai atau tidak. Atau dapat dikatakan pengujian terhadap alat ukur yang dipakai untuk mengetahui validasi variabel yang digunakan dalam penelitian ini menggunakan korelasi product moment dengan bantuan program SPSS 22.00. Suatu item pertanyaan dinyatakan valid jika nilai koefisien korelasi ( $\mathrm{r}_{\text {hitung }}$ ) melebihi nilai $\mathrm{r}_{\text {tabel }}$ pada tingkat signifikasi $5 \%$ dan $\mathrm{N}=64$ yaitu sebesar 0,204

\begin{tabular}{llrr}
\multicolumn{4}{c}{ Tabel 3. Uji Validasi } \\
\hline & Correlations & \multicolumn{1}{c}{ Kinerja } & \multicolumn{1}{c}{ BudayaO } \\
\hline Pearson Correlation & Kinerja & 1,000 &, 833 \\
& BudayaO &, 833 & 1,000 \\
Sig. (1-tailed) & Kinerja &. &, 000 \\
$\mathrm{~N}$ & BudayaO &, 000 & \\
& Kinerja & 64 & 64 \\
& BudayaO & 64 & 64 \\
\hline
\end{tabular}

Dari tabel 3 bahwa $\mathrm{r}_{\text {hitung }}$ (pearson correlation) dengan menggunakan SPSS 22 lebih besar dari $r_{\text {tabel }}($ $\mathrm{r}_{\text {hitung }}>\mathrm{r}_{\text {tabel }}$ ) atau $0,833>0,204$, ini memberi makna bahwa semua data dari variabel dependent maupun variabel independen dapat digunakan atau semua data valid.

\section{Uji Reliabilitas.}

Reliabilitas adalah sejauh mana hasil suatu pengukuran dapat dipercaya. Implikasinya hasil pengukuran dapat dipercaya apabila dalam beberapa kali pengukuran terhadap kelompok/subjek yang sama diperoleh hasil yang relatif sama. Dalam penelitian ini reliabilitas ditafsirkan dengan menggunakan koefisien Alpha Croncbach $(\alpha)$. Suatu variabel dikatakan reliabel jika nilai koefisien alphanya lebih dari 0,361 . 
Tabel 4. Uji Reliabilitas

\begin{tabular}{cc}
\hline Cronbach's Alpha & N of Items \\
\hline, 903 & 2 \\
\hline
\end{tabular}

Menurut Supandi (2013:98) suatu instrumen dinyatakan reliabel bila nilai alphanya lebih besar dari nilai rtabel. Dari tabel 4 bahwa instrumen memiliki nilai Cronbach's alpha lebih besar dari nilai $r_{\text {tabel }}(0,903>$ $0,204)$ sehingga disimpulkan bahwa instrumen penelitian adalah reliabel atau layak untuk dijadikan data pada penelitian ini.

\section{Regresi Linear Sederhana}

Regresi linear sederhana dengan digunakan dalam penelitian ini dengan tujuan untuk memasukkan data yang diteliti kedalam suatu model persamaan regresi dan membuktikan hipotesis mengenai diduga adanya pengaruh signifikan antara variabel independen (budaya organisasi) terhadap variabel dependen (kinerja karyawan). Dengan menggunakan software, yang bernama program SPSS versi 22.0 diperoleh perhitungan sebagai berikut :

Tabel 5. Regresi Linear Sederhana

\begin{tabular}{|c|c|c|c|c|}
\hline \multirow{2}{*}{\multicolumn{2}{|c|}{ Model }} & \multicolumn{2}{|c|}{ Unstandardized Coefficients } & \multirow{2}{*}{$\begin{array}{c}\text { Standardized Coefficients } \\
\text { Beta }\end{array}$} \\
\hline & & $\mathrm{B}$ & Std. Error & \\
\hline \multirow[t]{2}{*}{1} & (Constant) & 5,295 & 1,144 & \\
\hline & BudayaO &, 713 &, 060 & ,833 \\
\hline
\end{tabular}

Pada tabel 5, dapat diperoleh koefisien regresinya adalah sebesar 5,295 dan koefisien untuk variabel bebas (X) adalah sebesar 0,713. Dengan demikian model persamaan regresi yang dapat dituliskan dari hasil tersebut dalam bentuk persamaan regresi yakni ; $\mathbf{Y}=$ $5,295+0,713 X+e$

\section{Uji Hipotesis}

Uji t

Uji statistik t digunakan untuk mengetahui apakah variabel independen mempengaruhi secara signifikan terhadap variabel dependen. Dengan menggunakan tingkat signifikan menggunakan $\alpha=5 \%$ (signifikansi 0,05 , adalah ukuran standar yang sering digunakan dalam penelitian). Menentukan $t_{\text {hitung }}$ dengan menggunakan tingkat keyakinan 95\%, $\alpha=5 \%$ dengan disiplin kerja derajat kebebasan (df) n-k-1 atau 64-1-1 = 62, ( $\mathrm{n}$ adalah jumlah data dan $\mathrm{k}$ adalah jumlah variabel independen). Maka $t_{\text {tabel }}(\alpha=0,05$, df $=62)$ diperoleh sebesar 1,670. Dari perhitungan regresi output coefficients dapat diketahui $\mathrm{t}_{\text {hitung }}$ dalam tabel 6 sebagai berikut :

Tabel 6. Uji Statistik $\mathbf{t}$

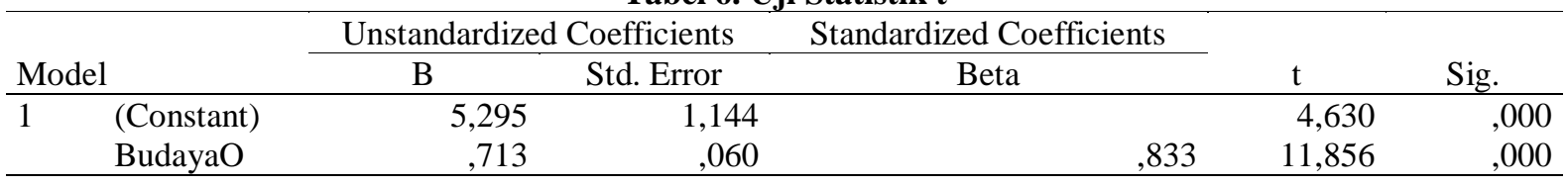

Tabel 6, diperoleh angka thitung budaya organisasi sebesar 11,856 Pengujian statistik t dilakukan dengan membandingkan nilai $t_{\text {hitung }}$ dengan $t_{\text {tabel. }}$ Dari pengujian maka dapat dijelaskan sebagai berikut : Pengujian Variabel budaya organisasi kerja. Dari hasil perhitungan uji secara diperoleh nilai $t_{\text {hitung }}$ sebesar 11,856 dan nilai probabilitas signifikansi 0,000 . Hal ini berarti budaya organisasi berpengaruh signifikan terhadap kinerja karyawan karena nilai signifikansi $0,000<0,05$. Dan $t_{\text {hitung }}>t_{\text {tabel }}(11,856>1,670)$, maka dapat disimpulkan bahwa disiplin kerja berpengaruh signifikan terhadap kinerja karyawan.

\section{Koefisien Korelasi dan Determinasi}

Korelasi adalah suatu parameter untuk ukuran seberapa kuat atau erat antara variabel indenpenden dengan variabel dependen. Sedangkan koefisien determinasi $\left(\mathrm{R}^{2}\right)$ pada intinya mengukur seberapa jauh kemampuan model dalam menerangkan variabel- variabel dependen. Apabila $\mathrm{R}^{2}$ mendekati satu (1) maka dapat dikatakan semakin kuat model tersebut menerangkan variasi variabel independen terhadap variabel dependen. Sebaliknya jika $R^{2}$ mendekati nol (0) maka semakin lemah variasi variabel independen menerangkan variabel-variabel dependen. Berdasarkan hasil output SPSS 22.00 besarnya nilai $r$ dan nilai $R^{2}$ dapat dilihat pada tabel 4.14 sebagai berikut :

Tabel 7. Koefisien Korelasi dan Determinasi

\begin{tabular}{lcccc}
\hline Model & R & R Square & $\begin{array}{c}\text { Adjusted R } \\
\text { Square }\end{array}$ & $\begin{array}{c}\text { Std. Error of the } \\
\text { Estimate }\end{array}$ \\
\hline 1 &, $833^{\mathrm{a}}$ &, 694 &, 689 & 1,49319 \\
\hline
\end{tabular}

Dari tabel 7 didapat korelasi atau nilai $\mathrm{r}$ yaitu sebesar 0,833 atau $83,3 \%$ yang berarti menunjukkan bahwa terjadi adanya hubungan yang sangat erat diantara variabel independen (Budaya Organisasi) dengan variabel dependen (Kinerja Karyawan). Dari 
tabel 4.17 juga dapat dilihat nilai Koefisien Determinasi $\left(\mathrm{R}^{2}\right)$ sebesar 0,694 atau 69,4\% variasi Kinerja karyawan yang bisa dijelaskan oleh variasi dari variabel independen yaitu budaya organisasi, sedangkan sisanya 22,5\% dijelaskan oleh faktor lain diluar penelitian.

\section{SIMPULAN}

Bahwa pelaksanaan budaya organisasi dan kinerja karyawan pada PT Angkasa Pura II (Persero) Sultan Thaha Jambi, menunjukkan kategori baik. Dimana pada variabel budaya organisasi skor rata-ratanya sebesar 253 kategori tinggi. Indikator pada variabel budaya organisasi yang tertinggi adalah indikator mengedepankan misi organisasi dan indikator motivasi yakni sebesar 258 kategori tinggi. Dilain sisi variabel kinerja karyawan skor rata-rata indikatornya sebesar 259 kategori baik. Dimana indikator variabel kinerja karyawan yakni kualitas kerja memiliki skor tertinggi yakni sebesar 268 kategori sangat baik. Didapat model persamaan regresi sederhana pada penelitian ini yakni; $Y$ $=5,295+0,713 \mathrm{X}+\mathrm{e}$. Sedangkan dari uji $\mathrm{t}$ disimpulkan bahwa budaya organisasi berpengaruh positif dan signifikan terhadap kinerja karyawan pada PT Angkasa Pura II (Persero) Sultan Thata. Hal ini ditandai dengan $t_{\text {hitung }}>t_{\text {tabel}}$, serta pro.sig $(0,004)<\alpha$ $(0,05)$.

\section{DAFTAR PUSTAKA}

Alwi, 2014, Manajemen Sumber Daya Manusia Suatu Konsep, PT. Remaja Rosdakarya, Bandung

Fathoni, 2016, Sumberdaya Manusia Suatu Konsep, Edisi Khusus, PT Tiga Raksa, Jakarta

Handoko, T. Hani, 2015, Manajemen, Edisi Revisi, PT. Ghalia Indonesia, Jakarta

Hasibuan, Malayu SP. 2012. Manajemen Sumber Daya Manusia, Edisi Revisi, Penerbit Bumi Aksara. Jakarta

Umar Husein 2013, Riset Sumber Daya Manusia, Gramedia Pustaka Utama, Jakarta

Istijanto . 2009. Aplikasi Riset. PT. Gramedia Pustaka Utama. Jakarta

Kaswan, 2012, Manajemen Sumber Daya Manusia Untuk Keunggulan Bersaing Organsiasi, Graha Ilmu, Yogyakarta

Mangkunegara, Anwar Prabu 2014, Manajemen Sumber Daya Manusia, Edisi Kelima, PT. Remaja Rosdakarya, Bandung

Mondy, 2014, Manajemen Sumber Daya Manusia Suatu Konsep dan Teori, Edisi Ketiga, PT Erlangga, Jakarta.

Rangkuti, Freddy, 2011, Pengantar Statistik, Penerbit Gramedia, Jakarta

Robbins, S Stephen, 2008, Perilaku Organisasi, Penerbit Salemba Empat, Jakarta

Sedarmayanti, 2003, Sumber Daya Manusia dan Produktivitas Kerja, CV. Mandar Maju. Bandung

Simamora, 2017, Manajemen Kepegawaian, Ghalia, Jakarta
Simanjuntak, Payaman, 2011, Manajemen dan Evaluasi Kinerja, FEUI, Jakarta

Stoner, 2013, Manajemen, PT. Gramedia, Jakarta

Sutrisno, 2015, Manajemen SumberDaya Manusia, PT. Raja Grafindo Persada, Jakarta

Sunyoto, Danang, 2013, Teori, Kuesioner dan Analisis Data Sumber Daya Manusia, CAPS, Jakarta

Supardi, 2013, Aplikasi Statistika Dalam Penelitian, Change Publication, Jakarta

Sutrisno, Edy, 2011, Manajemen Sumber Daya Manusia, Kencana Prenada Media Group, Jakarta

Suwatno ,2011, Manajemen Sumber Daya Manusia, CV. Alfabeta, Bandung

Sugiyono 2016, Metodelogi Penelitian Kuantatif, Kuantatif dan $R \& D$, Liberty, Bandung.

Rivai, Veithzal, 2015, Kepemimpinan dan Perilaku Organisasi, PT Rajagrafindo Persada, Jakarta

Wibowo, 2011, Perilaku Dalam Organisasi, PT. Rajagrafindo, Jakarta. 